\author{
Fidan Hasan MAJIDOVA \\ Western Caspian University \\ E-mail: fidan_mejidova@wcu.edu.az
}

\title{
THE TRANSLATION OF SIMILES FROM RUSSIAN INTO ENGLISH
}

\begin{abstract}
Abstarct: The research revealed the use of similes in Russian and English langua- ges. There are many examples taken from the works of the famous writers compared with their translation in Russian. In some cases, the translation shifts were undertaken by the translators which led to some translation losses of the target text. The translation losses were unavoidable due to some natural causes such as lack of the equivalent or analogous simile in the Russian language, in which cases the translators resorted to other stylistically marked elements, namely to metaphors or metonymy.

The second reason of translation losses lies in the fact of translators' style and preferences, as well as due to the difference in the structures of the two languages and the necessity to comply with the standards and norms of the tar- get language.

The conclusion of the article summarizes the level of the adequacy of translations into Russian, the adequacy being achieved by means of translation compensation of the lost emotive elements. The article is written considering scientific research methods, novelty and actuality. The great number of examples taken from the original and the translations of the novels and their comprehensive analysis testify the completeness and usefulness of the article. The theoretical and practical results of the articles can be used by the students and professors of the schools of humanities and linguistics of universities.
\end{abstract}

Keywords: translation comparison, translation difficulties, English, Russian.

UOT: 81

DOI: doi.org/10.54414/mumr8774

\section{Introduction}

The branch of linguistics very familiar to all students of philology is stylistics. Stylistics - the science of the use of language, exploring the principles and the effect of the choice and use of lexical, grammatical, phonetic and general linguistic resources for the transmission of thoughts and emotions in different contexts of communication. The most interesting stylistic devices are "simile" or "colorful comparison."

\section{Main part}

Simile - is the comparison of two completely different objects. The one which compared is called the tenor, the one with which is compared is vehicle. The tenor and vehicle are connected by this links: "like", "as", "as though", "as if", "as like", "such as", "as ... as", etc. More common among them are the link words "like" and "as".

Consider the following simile:

Maryam is like an angel. Its meaning is certainly not "Maryam is an angel". Because Maryam is a real person, "angel" is something mythic. Here "angel" is an abstract object, something special, carrying a positive meaning, with which a girl compared. Therefore, we can omit the simile and say: Mar- yam's personality is perfect. As it is 
seen simile makes the sentence more expressive and colorful. Another interesting example: She is like a turtle. The meaning: She is very slow. Taking into consideration that a woman compared with an animal "turtle", we come to conclusion that it is simile, not comparison.

Comparison and simile are fundamentally enough different phenomena that differ in the contexts in which they can have a meaningful role. It is too easy to differentiate them, knowing that comparison - when two common objects are compared with each other but simile compares two unlike objects. Surely, simile is more expressive, colorful and interesting. Using simile in poems attracts the reader's attention with its expressiveness.

The most impressive example of it are the lines in Robert Burns's poem, which sound like

"O my Luve's like a red, red rose That's newly sprung in June;

O my Luve's like the melody That's sweetly played in tune."

There are two similes in these lines. In the first writer compares the woman he loved with a red rose. It can be explained in many ways. His love is very valuable, as a red rose is the most expensive among the flowers. From the other point of view, his love is young as a new sprung rose. The second simile is "like a melody" where the author compares his love with something, what fills his soul. Here, it is a melody.

Edgar Allan Poe, the famous short story writer, used many similes in his work. For this reason, his stories are so colorful and impressive. In "Berenice", he writes: "I felt a terrible fear pressing down like a great stone on my heart." "Like a great stone" is translated into Russian as "как камень", and it is considered as a simile. Another, example taken from the same story sounds like this: She, Berenice, was as white as snow." Она была бела как снег. It proves again that similes make the reading exciting.

In order to translate the simile, it is very important to identify the two objects with each other and find out common features between them. For example, the sentence: 'The mind is like a computer' leads the hearer to think how the two concepts might be comparable: both take in, process and store information. In a conversation marveling at the complexity of the human brain, or a heavily rhetorical speech about human nature, the metaphor might be more suitable.

Most of the similes have their equivalents in Russian, it makes easy to translator to transfer the meaning and expressiveness to the target language reader.

The simile form is more likely to find out literal properties of the vehicle, otherwise the metaphor form evokes more emergent properties not applicable to the literal vehicle. In order to explain the simile, let us take as an example this sentence "Some ideas are like diamonds", where the subjects represented by adjectives describe ideas such as "rare and seldom" and "valuable". The metaphor 'Some ideas are diamonds', subjects tended to respond more meta- phorically: "brilliant and insightful", "fantastic and creatively very unique" [1].

Another interesting example of simile is "like five-star treatment", which sounds in Russian as "как 33 удовольствия". There is not any connection bet- ween the words treatment and five stars. Therefore, it helps to identify it as a simile.

So the simile "like a volcano" means that a person is very fast in his deals; "like an encyclopedia" means that a person is well educated. 
In order to show how deep and wealthy the language is - it is important to use the adjectives. Adjectives help to make impresssion on a listeners and readers, making the speech more colorful and impressive.

Similes always focus on features of an object more than the force with which the point is being made

In the famous play written by Bernard Shaw "Pygmalion" there is a good example of translator's work. Eliza throws Professor Higgins: "I am nothing to you - not so much as them slippers" - and the first thing, which attracts reader's attention, is excitement of the case, an error in the form of a demonstrative pronoun. There should be "Those slippers" instead of "them slippers". Howe- ver, we should take into consideration the feelings, which an author tried to transfer, because Eliza was a poor uneducated girl. Therefore, her speech cannot be perfect. When transferring the stylistic figures of speech - comparisons, metaphors, similes etc. an interpreter needs to make the most appropriate deci- sion while choosing the words.

For example, the simile "as like as two peas", may easily be replaced, with "alike as two drops of water", which is its equivalent. The meanings are the same.

Another interesting method of translation of similes is descriptive method. Using this method translator just transfers the meaning and sometimes it makes it more impressive. For example: the simile "as big as life" sounds more impressive in descriptive translation "a life-size".

Quite often, the literal translation is impossible and requires replacement. Each case leads to occasional formations, implying an individual and creative approach.

Various types of simile are available. Among them conventional and encyclopedic similes are more common. They can pose troubles to translator. Before discussing some examples given below, it is better to try to indicate the suitable strategies to translate similes.

For example: This bread is as tough as old boot leather. In Russian, it sounds like:

Хлеб жесткий как бревно.

In conclusion, it is idiomatic translation. While translating it into Russian we managed to find out its equivalent.

In syntax, the structure of such kind of expressions, as well as their meaning is fixed. We can look up them in special dictionaries as well.

In dictionary, it is given in predicative position: to be (is) + as + Adjective + as + NP. The adjective, quite ordinary and simple in most cases and it is often interpreted literally. While, the NP is the vehicle, which is translated and interpreted non-literally. The function of NP consists of intensifying the mea- ning of the adjective and making it more impressive [1, 150-152].

Another interesting question is:

Which nouns can be selected as vehicles?

The nouns selected as vehicles must have something common with humans, animals, objects in order to attribute certain characteristics. Certainly, only adjectives can describe person's character. Unlimited adjectives can be used for this reason. Therefore, while saying sentence, we are emphasizing the idea of toughness.

The second type of simile is conventional simile. This type of simile is rather informal. Conventional type of simile often occurs, like other types of idioms, in written forms in many genres. The best example of it is journalistic text [1, 244, 264-268]. The choice of the entity used as vehicle is culture-bound. Anyway, it is posing a lexica-cultural trouble. Conventional type of simile, can easily 
be found in the most important and interesting Longman Dictionary of English Idioms.

Here are some examples taken from the Longman Dictionary of English Idioms with their Russian definitions.

As busy as a bee - занят как пчела. This is more common used in many languages in the world. Here the person is compared with a bee, which is one of the most diligent animals of the world.

As old as the hills - стар как горы. Here any object or person is compared with the hills, because of their age.

As easy as two and two- легко как дважды два.

In translating of these expressions, a translator should use different strategies. It also depends on a context.

For example: "to eat like a pig", is interpreted into Russian as "есть как свинья". So, the translation is made on the literal level.

"To work like a dog" is interpreted into Russian as "работать как собака", "like a slave". Here, one vehicle is replaced with a different vehicle.

As we can see, in several cases, the two cultures select two different vehicles to express.

The following example is:

He is as pleased as Punch.

While target readers may not have knowledge needed to interpret the simile, the translator should do his best in order not to show the gap between target and source languages. The translator will first define their common background knowledge.

The translating of similes can make many troubles. The main task of it is to represent that a simile is translatable. However, it is rather hard to translate. The translator should choose which potential translation strategies are better to adopt. The translator, thinking of macro factors, such as readership and genre, can decide this. Certainly, he must not forget about micro factors. Type, struc- ture and function of the simile are micro factors. Its relevance to the message is available in the target language.

Professional translator uses the methods of transmission of certain sty- listic devices used in the original in order to make the text more brightness and expressiveness. At all times, translators faced with a dilemma: either to try to copy the original reception, or if the first is not possible to create a translation own stylistic means having the same emotional artistic effect. This is a principle part of the stylistic. It is possible to transmit grammatical means of expression by the lexical one and vice versa.

\section{References:}

1. Glucksberg, S. and Haught, C. 2006. On the relation between metaphor and simile: When comparison fails. Mind and Language 21 (3): 360-378.

2. The Longman Dictionary of English Idioms 1980.

\section{Фидан Хасан кызы МАДЖИДОВА \\ Западно-Каспийского Университет \\ E-mail:fidan_mejidova@wcu.edu.az}

\section{СРАВНИЙ ПЕРЕВОДОВ С РУССКОГО НА АНГ ДИЙСКИЙ ЯЗЫК}

Резюме: Данная статья посвящена использованию и переводу сравнений на русском и английском языках. Примеры употребления сравнений взяты из произведений таких 
известных писателей как Э.А. По «Берениса», Бернард Шоу «Пигмалион» и сопоставлены с переводом на русский язык.

Не исключены случаи опущения сравнений переводчиком, приводящие к некоторым потерям целевого текста. Потери при переводе неизбеж-ны из-за некоторых естественных причин, таких как отсутствие эквива- иентного или аналогичного сравнения в русском языке, и в этом случае переводчики прибегают к другим стилистически маркированным элементам, а именно к метафорам или метонимиям.

Вторая причина потери перевода закдючается в факте стиля и предпочтений переводчиков, а также из-за раздичий в структуре двух языков и необходимости соблюдения стандартов и норм.

В статье говориться о трудностях, с которыми сталкивается перевод чик стараясь не утратить эмоциональность, выраженную стилистическими единицами.

Статья написана с учетом методов научных исследований, новизны и актуадьности. Множество примеров, взяты из оригинала и переводов романов. Теоретические и практические результаты статьи могут быть исподьзованы студентами и преподавателями гуманитарных и дингвистических вузов.

Ключевые слова: сравнение перевода, трудности перевода, английский язык, русский язык.

\author{
Fidan Həsən q1zı MəCIDOVA \\ Qarbi Kaspi Universiteti \\ E-mail: fidan_mejidova@wcu.edu.az
}

\title{
BONZOTMOLORIN RUS DİLINDON İNGIILIS DİLINO TORCÜMəSİ
}

Xülasə: Məqalədə rus və ingilis dillərində müqayisələrin istifadəsindən danışılır. Məşhur yazıçıların əsərlərində istifadə olunmuş müqayisələr rus dilində tərcü- mələri ilə qarşılaşdırılıb müzakirə olunur. Bəzi hallarda tərcümə dəyişikliyi tər-cüməçilər tərəfindən həyata keçirilir və bu da əsas mətndə bəzi itkilərə səbəb olur. Tərcümə itkiləri, rus dilində ekvivalent və ya oxşar müqayisələrin olmamasına görə qaçılmazdır. Bu zaman tərcüməçilər digər stilistik elementlərə, yəni metafora və ya metonimiyə müraciət edirlər.

Tərcümə itkisinin ikinci səbəbi tərcüməçilərin tərzi və üstünlükləri, habe-lə iki dildə quruluş fərqliliyi və hədəf dilin standart və normalarına uyğun olma-ğın zəruriliyi ilə əlaqədardır.

Məqalənin sonunda itirilmiş duyğusal elementlərin tərcümə yolu ilə əldə olunmasından danışılır.

Məqalə elmi tədqiqat metodları, yenilik və aktuallıq nəzərə alınmaqla ya- zılmışdır. Romanlardan və tərcümələrindən götürülmüş çox sayda nümunə və onların hərtərəfli təhlili məqalənin tamlığına və faydalılığına dəlalət edir. Məqalənin nəzəri və praktik nəticələrindən universitetlərin humanitar və dilçi- lik şöbələrinin tələbə və müəllimləri istifadə edə bilər. Açar sözlər: tərcümə müqayisəsi, tərcümə çətinlikləri, Ingilis dili, rus dili.

Daxil olub: 18.10 .2021 